\title{
Experiences of capacity strengthening in sanitation and hygiene research in Africa and Asia: the SHARE Research Consortium
}

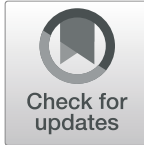

Belen Torondel ${ }^{1 *}$ DD, Emily Balls ${ }^{1}$, Caroline Cleopatra Chisenga ${ }^{2}$, Save Kumwenda ${ }^{3}$, Elialilia Okello ${ }^{4}$, Sheillah Simiyu ${ }^{5}$, Tracy Morse ${ }^{3}$, Kyla Smith ${ }^{6,7}$, Jane Mumma ${ }^{5}$, Joseph Banzi ${ }^{6,7}$, Erik Harvey ${ }^{6,7}$, Kondwani Chidziwisano ${ }^{3}$, Jenala Chipungu ${ }^{2}$, Heiner Grosskurth ${ }^{4}$, Amani Beda ${ }^{4}$, Saidi Kapiga ${ }^{1,4}$, Joanna EstevesMills ${ }^{1}$, Oliver Cumming ${ }^{1}$, Sandy Cairncross ${ }^{1}$ and Roma Chilengi ${ }^{2}$

\begin{abstract}
The Sanitation and Hygiene Applied Research for Equity (SHARE) Research Programme consortium is a programme funded by the United Kingdom Department for International Development (DFID) that aims to contribute to achieving universal access to effective, sustainable, and equitable sanitation and hygiene worldwide. The capacity development component is an important pillar for this programme and different strategies were designed and implemented during the various phases of SHARE. This paper describes and reflects on the capacity-building strategies of this large multi-country research consortium, identifying lessons learnt and proposing recommendations for future global health research programmes. In the first phase, the strategy focused on increasing the capacity of individuals and institutions from low- and middle-income countries in conducting their own research. SHARE supported six PhD students and 25 MSc students, and organised a wide range of training events for different stakeholders. SHARE peer-reviewed all proposals that researchers submitted through several rounds of funding and offered external peer-review for all the reports produced under the partner's research platforms. In the second phase, the aim was to support capacity development of a smaller number of African research institutions to move towards their independent sustainability, with a stronger focus on early and midcareer scientists within these institutions. In each institution, a Research Fellow was supported and a specific capacity development plan was jointly developed.

Strategies that yielded success were learning by doing (supporting institutions and postgraduate students on sanitation and hygiene research), providing fellowships to appoint mid-career scientists to support personal and institutional development, and supporting tailored capacity-building plans. The key lessons learnt were that research capacity-building programmes need to be driven by local initiatives tailored with support from partners. We recommend that future programmes seeking to strengthen research capacity should consider targeted strategies for individuals at early, middle and later career stages and should be sensitive to other institutional operations to support both the research and management capacities.
\end{abstract}

Keywords: Sanitation and hygiene programme, capacity development, consortium, training, research

\footnotetext{
* Correspondence: belen.torondel@lshtm.ac.uk

'Department of Disease Control, London School of Hygiene and Tropical

Medicine, Keppel Street, London WC1E 7HT, United Kingdom

Full list of author information is available at the end of the article
}

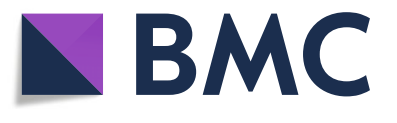

(c) The Author(s). 2019 Open Access This article is distributed under the terms of the Creative Commons Attribution 4.0 International License (http://creativecommons.org/licenses/by/4.0/), which permits unrestricted use, distribution, and

reproduction in any medium, provided you give appropriate credit to the original author(s) and the source, provide a link to the Creative Commons license, and indicate if changes were made. The Creative Commons Public Domain Dedication waiver (http://creativecommons.org/publicdomain/zero/1.0/) applies to the data made available in this article, unless otherwise stated. 


\section{Main Text \\ Introduction of SHARE programme and capacity-building component}

Basic toilets (facilities that safely separate human waste from human contact) and good hygiene practices are essential for the prevention of different diseases. A total of 2.4 million deaths could be prevented annually if everyone practised appropriate hygiene and had good, reliable sanitation and drinking water [1]. These deaths would be mostly among children in developing countries who suffer from diarrhoea and subsequent malnutrition, and from other diseases attributable to malnutrition [2]. Recent estimates suggest that, despite great progress, 2.3 billion people still lack even a basic sanitation service [3]. The dearth of this basic human right can have a profound effect on individuals' health, wellbeing and livelihoods, and this is reflected in the priority given to "adequate and equitable sanitation and hygiene for all" as part of Sustainable Development Goal 6 'Clean water and sanitation' [4]. Progress towards achieving universal access to this basic right is slow due to different political and economic reasons, but understanding evidence-based information of approaches and interventions that are the most effective in each setting are also crucial to achieve this progress.

The Sanitation and Hygiene Applied Research for Equity (SHARE) consortium was established in 2010 with exactly this purpose in mind - to contribute to achieving universal access to effective, sustainable and equitable sanitation and hygiene by generating, synthesising and translating evidence to improve policy and practice worldwide. The SHARE research consortium is led by the London School of Hygiene and Tropical Medicine (LSHTM) and started as a 5-year programme running from 2010 to 2015 with $£ 10$ million of funding from the United Kingdom Department of International Development. Throughout phase I, SHARE focused its activities on working closely with national sector partners from low- and middle-income countries (LMICs) to define research priorities and supported the generation of rigorous and relevant applied research. It also worked to enhance the uptake of new and existing research in accordance with the main research themes developed throughout the inception period (equity, health, markets and urban sanitation).

In late 2014, the Parliamentary Under-Secretary of State approved a $£ 6$ million cost extension, taking the programme through to December 2018. Phase II focused on four sub-Saharan African countries - Malawi, Kenya, Tanzania and Zambia. The extension was geared towards maximising the value for money of phase I, by securing the legacy and sustainability of phase I investments and furthering the research agenda in four thematic research areas in a more concerted manner
(Water, Sanitation and Hygiene (WASH) and complementary food hygiene, WASH and pro-poor urban sanitation, WASH and routine immunisation, and WASH and undernutrition). Throughout phases I and II, the SHARE programme has achieved its goals with a pioneering approach that focuses on four core activities, namely sanitation and hygiene research, researchinto-use, capacity development, and monitoring and evaluation.

Capacity-building has been an important and solid component responsible for the success of the SHARE programme. The gap in research capacity strengthening has been widely recognised as a major barrier for development in LMICs. Although there has been remarkable progress over the past two decades, it has been said that "research capacity in the South remains one of the world's unmet challenges" [5].

The capacity-building goal of the SHARE programme was to strengthen the capacity to sustain global sanitation and hygiene research by LMIC researchers and institutions. The research capacity-building activities of SHARE were aimed at maximising individual and institutional research capacity development by using different strategies. As such, the consortium worked with its research partners and other key sector stakeholders to support them in conducting research, interpreting research findings and applying these to their work. The aim of this paper is to summarise the capacity-building strategies conducted in this programme during phase I and II and highlight the lessons learnt that could be useful for future programmes.

\section{Capacity-building during SHARE phase I}

SHARE's capacity development activities focused on increasing the capacity of individuals and institutions to convene stakeholders, to conduct relevant and rigorous research, and to use evidence to inform hygiene and sanitation programmes and policies. The SHARE consortium's approach to capacity-building involved strategically designing research projects to build capacity within collaborating organisations. This was achieved through action research with advisory support from LSHTM, WaterAid, the International Centre for Diarrhoeal Disease Research, Bangladesh (ICDDR,B) and the International Institute for Environment and Development for collaborating partners.

In terms of specific training activities, the approach to capacity-building and strengthening comprised (1) structured mentoring integrated into the research, administration, financial management and communication activities; (2) specific training to address immediate gaps in skills; and (3) a $\mathrm{PhD}$ programme designed to build lasting research capacity within 
LMIC institutions (including non-governmental organisations and universities).

The structured mentoring has been an on-going activity in support of proposal development. To further strengthen the consortium's research capacity, we included external peer review of the research protocols by independent researchers not involved in the proposal development. This critical review helped researchers in refining and shaping their research proposals. Examples of other forms of mentoring included advisory consortium members supporting in-country partners in areas of training, project costing, financial management and procedures. During this period, SHARE encouraged the different research groups to have a balanced authorship contribution of authors from high-income country and LMIC institutions in publications resulting from their work. One strategy used was to request that each research group had to prepare a list of publications before the start of each project with a discussed and agreed authorship contribution.

SHARE funded six PhD students who were selected based on the quality of their suggested research and experience in research in their countries of origin (India, Malawi, Bangladesh, Kenya, Ghana and Nepal). The topics of research selected by the students were all related to sanitation and hygiene (described in Table 1) and mentors from LSHTM were selected to direct or co-direct their Theses. All the students completed their $\mathrm{PhD}$ within the duration of the programme and, so far, have published 17 open access peer-reviewed papers from their work. Another output is that, since then, SHARE phase I PhD students have formed networks among themselves in the WASH sector, which has resulted in different collaborations on new projects, an idea birthed during the London $\mathrm{PhD}$ training period.

SHARE also supported $25 \mathrm{MSc}$ students and facilitated 26 training courses and 52 knowledge-sharing events. It provided peer review for 48 research proposals submitted to different funding rounds and offered external peer review for the national platforms' research outputs.

\section{Capacity-building during SHARE phase II}

Phase II constituted a transition from phase I and aimed to increase SHARE's focus on building capacity in the target countries - Tanzania, Malawi, Kenya and Zambia. More specifically, phase II aimed to develop sector capacity with the view to ensuring the legacy of SHARE investments. In practice, this has required a transition away from investing in PhDs and MScs towards more established mid-career scientists from within SHARE partner institutions. This move aims to enhance the retention of skills and knowledge within leading national WASH institutions while also maximising the reach of investment - mid-career scientists themselves offer capacity development and support to $\mathrm{PhD}$ and $\mathrm{MSc}$ students.

In order to achieve this purpose, two main strategies were used, namely (1) a Research Fellow was appointed and supported for 24 months in each of the four targeted institutions $(£ 52,500)$ and $(2)$ all four national research partners were awarded $£ 40,000$ to implement their own capacity development plans.

\section{Research Fellows}

The four Research Fellows have been involved directly in their institution's research programme, whilst also being encouraged to develop their own research agenda. A specific terms-of-reference document was designed for each of them with the aim that they would mobilise resources for sustaining their position. Each fellow had a personal development plan, to the value of $£ 6000$, that could be utilised for training, attending conferences and network meetings, among others. All the Research Fellows have been participating actively in their research programmes and have been helping to

Table 1 Description of PhD student projects funded in SHARE phase I

\begin{tabular}{|c|c|c|}
\hline PhD student & Title & Country \\
\hline Dr Richard Chunga & $\begin{array}{l}\text { Modelling household sanitation technology choices } \\
\text { in peri-urban areas in Blantyre and Lilongwe, Malawi: } \\
\text { a revealed preference approach }\end{array}$ & Malawi $[6,7]$ \\
\hline Dr Parimita Routray & $\begin{array}{l}\text { Gender and sanitation in Odisha, India: implications } \\
\text { for intervention strategies }\end{array}$ & India [8-10] \\
\hline Dr Sheillah Simiyu & $\begin{array}{l}\text { Socio-economic dynamics of sanitation in informal } \\
\text { settlements of Kisumu city, Kenya }\end{array}$ & Kenya [11-16] \\
\hline Dr Tarique Huda & $\begin{array}{l}\text { Role of sanitation in preventing contamination of the } \\
\text { domestic environment and protecting health, Bangladesh }\end{array}$ & Bangladesh [17] \\
\hline Dr Prince Antwi-Agyei & $\begin{array}{l}\text { Wastewater in use in urban agriculture in Ghana: } \\
\text { an exposure and risk assessment in Accra, Ghana }\end{array}$ & Ghana [18-22] \\
\hline Dr Om Prasad Gautam & $\begin{array}{l}\text { Food hygiene intervention to improve food hygiene } \\
\text { behaviours, reduce food contamination and diarrhoeal } \\
\text { disease burden in Nepal }\end{array}$ & Nepal [23] \\
\hline
\end{tabular}


develop the capacity of other students and research staff within their institutions. All of them have been actively involved in developing their careers and in participating in workshops and conferences inside and outside their countries. In Table 2, we summarise key activities involved and show specific examples of where they have been working to ensure the sustainability of their positions within their institutions.

In order to motivate Research Fellows to apply to different funding opportunities, a monthly rota for sharing funding opportunities was created among them. The opportunities were shared with all the SHARE members, and Research Fellows were encouraged to share within their institutions.

\section{Capacity development plans}

Each partner developed their own research capacity plans by identifying several small capacity gaps that needed to be addressed. All the activities mainly aligned across five topics - increase in WASH sector capacity; increase in contribution to scientific evidence; increase in dissemination and use of evidence; increase in clinical/technical or administrative skills within the institution; and improved access to technical and information technology software and tools. The capacity development manager role supported partners to organise and execute these capacity development plans. Table 3 describes the different capacity development outcomes and inputs planned by each partner.

SHARE LSHTM members and other researchers from the Environmental Health Group at LSHTM, provided continuous and responsive capacity development to all SHARE partners. This support aligned directly with partner capacity development plans and other changing needs arising during project development. Planned technical support for SHARE research partners included the following:

- Point-of-use support: Provided, usually remotely, by the SHARE Finance Officer, Administrator and Chief executive officer when difficulties were encountered by partners in the submission of financial, management and resources data support.

- Mentoring: Provided to cover specific needs, especially for senior research and management staff as well as junior academics. Mentoring was usually organised by the capacity-building manager and provided remotely by Skype or during field visits by SHARE staff or researchers from the environmental health group and responded directly to the needs of SHARE partner staff. Mentoring focused on the following topics: scientific skills such as writing academic papers or conference presentation or using referencing software, methods of analysis of scientific data, research uptake, grant management support and advice about career development.

- Support for outcome mapping and research-into-use: Each of the partners was supported to create outcome mapping documents to guide the implementation, monitoring and evaluation of their research-into-use work. This included identifying stakeholder outcomes across seven key groups national government, local government international agencies, non-governmental organisations and civil society, national research institutes, donors, and research participants [24]. For each stakeholder group, partners developed specific indicators defining the desired change in stakeholder behaviour as well as generating a list of research-into-use activities to influence stakeholders. Progress was followed through quarterly tracking and reporting tools.

SHARE partners were required to report on progress against their planned capacity development activities in their quarterly reports to the monitoring officer. Data was used to measure progress towards the overarching objectives of the capacity development work stream through a programme-monitoring logframe.

\section{Discussion and reflections}

The research capacity-building activities of SHARE were aimed at maximising individual and institutional research capacity development by using different strategies. The main strategies that yielded success were learning by doing (supporting institutions and postgraduate students on sanitation and hygiene research with different activities), providing fellowships to appoint mid-career scientists to support personal and institutional development, and supporting tailored capacity-building plans.

In phase I, SHARE's capacity development activities focused on increasing the capacity of individuals and institutions, whilst phase II constituted a transition from phase I and aimed to increase SHARE's focus on building capacity in higher research and education institutions from four target countries to ensure the legacy of SHARE. There was a clear transition from investing in $\mathrm{PhD}$ and MSc to more established middlecareer scientists, with a specific budget invested in retention of skills and knowledge within leading partners institutions. A key goal for sustainability of any African institution is to ensure that research staff are advancing in their career progression and consolidate their research skills. Barriers to this, such as poor funding and lack of protected time for research pursuits, have been a common complaint from African researchers [25], which is why the Research Fellows 
Table 2 Research fellow activities and contributions

\begin{tabular}{|c|c|c|c|c|}
\hline Institution & $\begin{array}{l}\text { Contributions to research } \\
\text { project }\end{array}$ & Training organised & $\begin{array}{l}\text { Training received/conference } \\
\text { attendance }\end{array}$ & Funding applications \\
\hline GLUK & $\begin{array}{l}\text { - Coordinating formative stage } \\
\text { of the main project } \\
\text { - Coordinating the main project } \\
\text { intervention } \\
\text { - Contributing to research into } \\
\text { use through stakeholder } \\
\text { meetings } \\
\text { - Leading the authorship of } \\
\text { two manuscripts and } \\
\text { contributing to other } \\
\text { manuscripts from the study }\end{array}$ & $\begin{array}{l}\text { - Reference management } \\
\text { training to PhD students } \\
\text { - Training on poster } \\
\text { development and qualitative } \\
\text { data analysis to Master's } \\
\text { students } \\
\text { - Training of research assistants } \\
\text { in methods of field data } \\
\text { collection } \\
\text { - Mentorship to PhD and MSc } \\
\text { students and supervising their } \\
\text { theses/dissertations } \\
\text { - Lecturing Master's and } \\
\text { undergraduate students a } \\
\text { course on basic research } \\
\text { methods }\end{array}$ & $\begin{array}{l}\text { - Training on transdisciplinary } \\
\text { research (Uganda, Aug 2017) } \\
\text { - GLUK annual conference } \\
\text { (November 2017) } \\
\text { - Africa Science Leadership } \\
\text { training (South Africa, March } \\
\text { 2018), organised by the } \\
\text { University of Pretoria } \\
\text { - Seedbeds of transformation } \\
\text { conference (May 2018, South } \\
\text { Africa), organised by Future } \\
\text { Earth } \\
\text { - Participant and panel } \\
\text { discussant in the Sustainable } \\
\text { African Cities Conference (July } \\
\text { 2018, Ghana) } \\
\text { - Participated in the WEDC } \\
\text { conference (July 2018) } \\
\text { - Participated in the International } \\
\text { Conference on Urban Health } \\
\text { (Nov 2018, Uganda) }\end{array}$ & $\begin{array}{l}\text { - Co-principal investigator on a } \\
\text { study on shared sanitation in } \\
\text { Kenya and Ghana, funded by } \\
\text { SIDA through the International } \\
\text { Science Council } \\
\text { - Co-principal investigator on the } \\
\text { 'Market to Mouth study', a 1-year } \\
\text { research study in collaboration } \\
\text { with University of lowa and } \\
\text { IFPRI, funded by IFPRI } \\
\text { - Study on faecal waste emptying } \\
\text { services in Kisumu, funded by } \\
\text { WSUP } \\
\text { - Three other applications were } \\
\text { made but were unsuccessful }\end{array}$ \\
\hline
\end{tabular}

MITU - Leading the qualitative research component of the Mikono Safi Intervention - Contributed to the ongoing parental engagement activities in intervention schools

- Lead on a formative research to develop methods to be used to measure mobility among women at high risk of HIV infection in fishing communities along Lake Victoria

- Leading the authorship of two publications and contributing to other manuscripts from the study

CIDRZ - Establish assays for testing environmental enteric dysfunction in serum and stool samples

- Support evaluation of rotavirus vaccine response and evaluation of factors negatively influencing vaccine uptake

- Profiled pathogens responsible for the aetiology of diarrhoea post-rotavirus vaccine introduction

- Leading the authorship of two publications and contributing to other manuscripts from the study

MEIRU - Participation in the intervention development, training of research assistants and monitoring of data

- Training and supervision of Group Coordinators

- Coordination of small research related to main protocol

- Coordinating publication development
- Co-facilitated a capacitybuilding session on the role of formative research in WASH in a WASH stakeholders' meeting

- Co-facilitated a research methods course conducted annually by MITU

- Provided qualitative methods training to junior research scientists participating in Mikono Safi and other projects at MITU

- Learning new methods of analysis by contributing to the analysis of qualitative data from the Women's Sanitation Vulnerabilities in Southern Tanzania, a funded SHARE project based in Iringa region

- Learning how to develop measures of mobility patterns among women with high risk of HIV infection in fishing communities along the Lake Victoria

- Poster presentation at UNC 2018

- Provide mentorship to three PhD students and one MSC student

- Participated at CIDRZ weekly research meetings

- Presentation to institution research team on all available grants

- Manuscript writing workshop

- Research methods courses (sample size determination mix method tools, role of bias and confounding,

how to conduct literature

reviews, systematic reviews and meta-analyses, monitoring and evaluation, how to use different research software)

- Learnt how to design and implement a clinical tria

- Learnt project management skills (currently managing three projects)

- Learnt grant writing skills

- Attended the roundtable SHARE meeting in Geneva

- Attended a EDCTP meeting in Johannesburg

- Attended the grant and manuscript writing at CAPRISA, Johannesburg

- Attended to in house Stata training within CIDRZ

- Attended a research methods conference in Tanzania organised by MITU and NIMR in February 2017

- Attended Partnership for African Social Governance Research Seminar in November 2017

- Presented at the College of Medicine Research
Contributed to grant applications: - Randomised controlled trial to assess the effectiveness of antiretroviral treatment and access to services case management intervention in increasing early linkage to HIV primary care

- Mixed methods study to assess reliability of using GPS trackers and mobility phones to study mobility patterns among women at high risk of HIV infection in fishing communities along the Lake Victoria (submitted to International AIDS Vaccine Initiative)
- Received an EDCTP grant (Career Development award) of 36 months duration, aiming to determine immunogenicity against the newly introduced cholera vaccine in a Zambian population

- Submitted grant applications to Welcome trust Career Fellowship Awards, Future Leaders - African Independent Research

Fellowships from the Royal Society of the United Kingdom

Applied to the African Public Health Leaders Fellowship (October 2018 to October 2019)

- Applied for the 2018

Demographic Health Surveys

Fellows Programme for University Faculty from Afghanistan, Cambodia, Ethiopia, Malawi, Myanmar, Nepal, South Africa, Timor-Leste, and 
Table 2 Research fellow activities and contributions (Continued)

\begin{tabular}{|c|c|c|c|c|}
\hline Institution & $\begin{array}{l}\text { Contributions to research } \\
\text { project }\end{array}$ & Training organised & $\begin{array}{l}\text { Training received/conference } \\
\text { attendance }\end{array}$ & Funding applications \\
\hline & $\begin{array}{l}\text { - Dissemination of research } \\
\text { protocol, progress and results } \\
\text { to stakeholders } \\
\text { - Leading the authorship of } \\
\text { one publication and } \\
\text { contributing to other } \\
\text { manuscripts from the study }\end{array}$ & $\begin{array}{l}\text { - Grant proposal writing course } \\
\text { - Integrating social science in } \\
\text { engineering and applied } \\
\text { science research course for } \\
\text { staff } \\
\text { - How get promoted through } \\
\text { research, consultancy, } \\
\text { teaching, university duties and } \\
\text { outreach for staff }\end{array}$ & $\begin{array}{l}\text { Dissemination Conference in } \\
\text { November } 2017 \text { in Malawi and } \\
\text { emerged best PhD presenter } \\
\text { - Attended a postgraduate } \\
\text { supervision course organised } \\
\text { by the Consortium for } \\
\text { Advanced Research Training in } \\
\text { Africa and College of Medicine } \\
\text { in Malawi in July } 2018 \\
\text { - Attended a monitoring and } \\
\text { evaluation course organised by } \\
\text { University of Witwatersrand in } \\
\text { Malawi in August } 2018\end{array}$ & Zimbabwe \\
\hline
\end{tabular}

CAPRISA Centre for the Aids Programme of Research in South Africa; CIDRZ Centre for Infectious Disease Research in Zambia; EDCTP European and Developing Countries Clinical Trials Partnership; GLUK Great Lakes University of Kisumu, Kenya; IFPRI International Food Policy Research Institute; MEIRU Malawi Epidemiology and Intervention Research Unit at the Polytechnic of the University of Malawi; MITU Mwanza Intervention Trials Unit, Tanzania; NIMR National Institute for Medical Research, Tanzania; SIDA Swedish International Development Cooperation Agency; UNC University of North Carolina at Chapel Hill; WASH Water, Sanitation and Hygiene; WEDC Water, Engineering and Development Centre; WSUP Water and Sanitation for the Urban Poor

scheme was a key success of the SHARE programme. Investing in postgraduate and doctoral studies in phases I and II was also an important achievement of the SHARE programme, as the need to provide more support for postgraduate training in health sciences in African universities is globally recognised [26, 27] if we are to increase the capacity of institutions. In both phases, locally driven research agendas were a priority. It has been seen from other programmes that externally dictated agendas have resulted in inappropriate projects unrelated to local research needs, which derived conclusions that did not have any direct local benefit [28, 29].

The SHARE consortium has managed to meet most, if not all, of its goals in the complex field of WASH. All phase I projects were completed and phase II projects are on their way to completion. The consortium projects have generated, synthesised and tested practice on current critical issues in the WASH sector. In the first phase, this included sanitation technology assessments; understanding gender and sanitation issues; the socioeconomic dynamics of sanitation to water use; and food hygiene in various contexts of LMIC settings. The second phase saw the consortium focus on supporting work on WASH and complementary food hygiene; WASH and pro-poor urban sanitation; WASH and routine immunisation; and WASH and undernutrition. Through these projects, a wealth of experience has been developed, with 114 peer-reviewed manuscripts published in international journals (Additional file 1: Table S1). Deliberate strategies were applied to distribute authorships between members of high-income countries and LMIC partner institutions; these achieved a good balance of authorship, in contrast with other programmes where power-imbalanced relationships resulted in more published work led by high-income country researchers
[28]. Perhaps most importantly, SHARE will leave a legacy through its support for sustainable capacity development that will live on decades after the consortium is closed. Formation of a peer network of researchers was the pivot of success of the SHARE programme - as a result nine networks were created during phase II of the project (Additional file 2: Table S2). At the end of this 8 -year programme, SHARE has effectively managed to roll out the capacity-building programmes for these nine networks (Tables 2 and 3), all aiming to orientate early- and middle-career researchers towards WASH research and equipping them with the necessary skillset needed to carry out scientific research.

The capacity-building strategies from SHARE have been successful at meeting programme goals because of three important factors that were considered during the programme. First, strategic national partner selection the partners selected within Africa and Asia were all established and had the required basic systems and structures in place to allow for the projects to run effectively. Thus, the SHARE project was an addition to bolster and support work within their mandates. Second, locally driven research agendas - while the partners' projects were invited to respond to a broad call, the research agenda was driven based on local needs and partner aspirations. Third, dedicated technical support and networking - networking activities were lined up throughout the SHARE programme. Structured milestone reporting on progress helped the projects identify areas of weakness early on and find mitigating solutions in good time.

The SHARE programme faced some administrative challenges in the implementation of its research and capacity-building activities. Different sets of administrative regulations across the institutions led to complications and delays in starting or sustaining certain capacity-building activities. 
Table 3 Capacity development plans

\begin{tabular}{|c|c|c|c|}
\hline Thematic Areas & & CIDRZ & GLUK \\
\hline \multirow[t]{2}{*}{$\begin{array}{l}\text { 1. Increase in } \\
\text { sector WASH } \\
\text { capacity }\end{array}$} & Outcome & $\begin{array}{l}\text { Build research capacity in } \\
\text { the WASH sector in } \\
\text { Zambia }\end{array}$ & $\begin{array}{l}\text { Build research capacity in } \\
\text { the WASH sector in Kenya }\end{array}$ \\
\hline & Input & $\begin{array}{l}\text { 1. SHARE scholar award } \\
\text { supports field research for } \\
\text { two Master's students at } \\
\text { the University of Zambia } \\
\text { on a WASH-related subject } \\
\text { 2. Funding to stimulate } \\
\text { innovative WASH designs } \\
\text { among engineering } \\
\text { students }\end{array}$ & $\begin{array}{l}\text { 1. SHARE scholar award } \\
\text { supports four grants for } \\
\text { Masters students at GLUK } \\
\text { to conduct WASH research } \\
\text { 2. One PhD student to } \\
\text { conduct research on } \\
\text { community health } \\
\text { volunteers and food } \\
\text { hygiene practices }\end{array}$ \\
\hline
\end{tabular}

2. Increase in contribution to scientific evidence

Graduate students, middle
Outcome CIDRZ junior staff develop scientific writing skills

Input

1. Host writing skills course

2. CIDRZ staff attend writing skills course level managers and policymakers build capacity in scientific writing

1. PhD student attended CIDRZ writing skills course 2. Organise workshop and symposiums on WASH 3. One publication by a Master's student 4. One publication by a PhD student
3. Increase in dissemination and use of evidence

\section{Outcome CIDRZ has an active Research into Use platform}

Input
Proactive scoping of key stakeholders nationally and scheduled engagement Dissemination of research through local and international events
GLUK disseminates research and evidence at national and international events

1. Dissemination of research through local and national stakeholder meetings

2. Participating in international conferences (World Water Forum, Stockholm, WEDC, UNC), International Conference of Urban Health

\begin{tabular}{|c|c|}
\hline MITU & MEIRU \\
\hline $\begin{array}{l}\text { Build research capacity in the } \\
\text { WASH sector in Tanzania }\end{array}$ & $\begin{array}{l}\text { Build research capacity in the } \\
\text { WASH sector in Malawi }\end{array}$ \\
\hline $\begin{array}{l}\text { 1. Host training on WASH } \\
\text { research methods and } \\
\text { scientific advances }\end{array}$ & $\begin{array}{l}\text { 1. Creation and delivery of six } \\
\text { training courses: } \\
\text { - Rigorous research and use } \\
\text { of data } \\
\text { - Data management and } \\
\text { analysis } \\
\text { - Monitoring and evaluation } \\
\text { - Geographic information } \\
\text { systems and remote sensing } \\
\text { - Financial management of } \\
\text { research grants } \\
\text { - Use of RANAS model in } \\
\text { WASH }\end{array}$ \\
\hline
\end{tabular}

Postgraduate students undertake specific WASH research

Postgraduate students undertake specific WASH research and develop skills for scientific writing

1. Funding of small research projects for MSc or PhD (×2) students

2. Individual attends CIDRZ writing skills course

1. Financial support to PhD students whose research is aligned with the SHARE II Malawi protocol

2. Workshops related to publication development 3. Three grants (13 in total including those from National Budget) for Master's students in WASH-related studies 4. Individual attended CIDRZ writing skills course

MITU disseminates research MEIRU increase sharing of and evidence at national and knowledge in the sector international events

1. Participation in international conferences (41st WEDC International Conference, Nakuru, Kenya; UNC Water and Health Conference 2018, North Carolina, USA)

Dissemination of research through national stakeholder meetings Environmental Sanitation
4. Increase in clinical/technical or administrative skills within the institution
Outcome Improve technical skills within CIDRZ

Input

\section{Funding for an} individual to attend a placement with a highquality grant management
Improve skills within GLUK Increase skills within MITU

1. Funding of workshops in biostatistics, and manuscript writing 2. Financial support for
1. Funding for research coordinator to attend two MSc modules at LSHTM 2. Admin team develop skills
1. Support for the Water and Network for Malawi to establish a working group for research and knowledge exchange, update website to support research dissemination and development of a repository, development and delivery of podcasts, and establishment of a database for WASH research

2. Prepared and hosted two national symposia (World Toilet Day 2017 and Global Hand Washing Day 2018) as knowledge-sharing events for researchers, practitioners and policy-makers

3. Provide funding for travel and advocacy

Increase skills within WASHTED

1. Developed and launched WASHTED strategic plan with support from SHARE

management team 
Table 3 Capacity development plans (Continued)

\begin{tabular}{|c|c|c|c|c|c|}
\hline Thematic Areas & & CIDRZ & GLUK & MITU & MEIRU \\
\hline & & $\begin{array}{l}\text { institution } \\
\text { 2. Support for short-term } \\
\text { training in ODK } \\
\text { programming for two } \\
\text { CIDRZ Data Managers } \\
\text { 3. Partial support for two } \\
\text { laboratory Research } \\
\text { Fellows to learn specific } \\
\text { skills in South Africa }\end{array}$ & $\begin{array}{l}\text { training in research ethics, } \\
\text { ODK and data } \\
\text { management, facilitated by } \\
\text { KEMRI } \\
\text { 3. Support for qualitative } \\
\text { data analysis training by } \\
\text { KEMRI } \\
\text { 4. Support for WASH } \\
\text { behaviour change } \\
\text { approaches by the team } \\
\text { from LSHTM } \\
\text { 5. Laboratory skills by the } \\
\text { team from University of } \\
\text { lowa } \\
\text { 6. One staff member to } \\
\text { receive short training in } \\
\text { research office } \\
\text { management } \\
\text { 7. One staff member to } \\
\text { receive short training in } \\
\text { grant financial } \\
\text { management }\end{array}$ & & $\begin{array}{l}\text { 2. Supported the } \\
\text { development and } \\
\text { management of lunch time } \\
\text { seminars accessible to all } \\
\text { personnel within UNIMA } \\
\text { 3. SHARE management team } \\
\text { provided administrative and } \\
\text { financial training during visits } \\
\text { to Malawi } \\
\text { 4. SHARE management team } \\
\text { provided mentoring to } \\
\text { WASHTED personnel }\end{array}$ \\
\hline \multirow{2}{*}{$\begin{array}{l}\text { 5. Improved } \\
\text { access to } \\
\text { technical and } \\
\text { information } \\
\text { technology } \\
\text { software and } \\
\text { tools }\end{array}$} & Outcome & $\begin{array}{l}\text { Access to institutional } \\
\text { licenses to enable } \\
\text { scientific capacity } \\
\text { development }\end{array}$ & $\begin{array}{l}\text { Access to institutional } \\
\text { licenses to enable scientific } \\
\text { capacity development }\end{array}$ & \multirow[t]{2}{*}{ N/A } & \multirow[t]{2}{*}{ N/A } \\
\hline & Input & $\begin{array}{l}\text { Purchase } 10 \text { EndNote } \\
\text { licenses; } 5 \mathrm{~N} \text {-vivo licenses } \\
\text { and five Stata licenses to } \\
\text { be installed on } \\
\text { institutional computers }\end{array}$ & $\begin{array}{l}\text { Purchase of statistical } \\
\text { analysis and reference } \\
\text { management software and } \\
\text { database }\end{array}$ & & \\
\hline
\end{tabular}

CIDRZ Centre for Infectious Disease Research in Zambia; GLUK Great Lakes University of Kisumu, Kenya; KEMRI Kenya Medical Research Institute; LSHTM London School of Hygiene and Tropical Medicine; MEIRU Malawi Epidemiology and Intervention Research Unit at the Polytechnic of the University of Malawi; MITU Mwanza Intervention Trials Unit, Tanzania; ODK Open Data Kit; RANAS Risks, Attitudes, Norms, Abilities, and Self-regulation; SHARE Sanitation and Hygiene Applied Research for Equity; UNC University of North Carolina at Chapel Hill; UNIMA University of Malawi; WASH Water Sanitation and Hygiene; WASHTED Water Sanitation Health and Appropriate Technology Development, Malawi; WEDC Water, Engineering and Development Centre

Another challenge for the appointed Research Fellows was to balance their work burden as they were involved in the programme research activities as well as the training and support for their institutions and their own development. A mitigation strategy for future programmes is to create an appropriate work plan that should be always agreed on and monitored by their line managers.

The approaches described above focus on individuals and provides relatively quick and quantifiable training outputs; these approaches serve as the backbone of human resource development for national research systems. However, without a coordinated national plan and a strong enabling environment to support trained scientists, brain drain is still likely to occur [30].

\section{Conclusions}

Global health partnerships and international research collaborations have enormous potential to improve the WASH situation and policy in Africa and Asia. A good capacity-building component should be included in all collaboration programmes; such an approach is more likely to help the sustainability of these institutions and to generate long-term changes in policy and practice that make real and sustained improvements with regard to sanitation and hygiene issues. Trusted long-term, high-income country collaborations that understand the context and needs of the region can teach agenda-setting skills and assist in agenda development [31], but LMIC researchers should be the leaders who dictate research agendas in their countries [29], as has been the case in the SHARE programme.

\section{Recommendations}

1. Research capacity-building activities need to be planned and tailored with each research partner institution.

2. Investments in middle-research careers are important to contribute to the strengthening of research institutions and to promote sustainability.

3. Mentoring, training and participation of postgraduate students in research projects co-led by 
high-income country researchers provide a great opportunity for co-learning and capacity strengthening.

4. Incorporation of networking activities in capacitybuilding plans offers an opportunity of future collaborations.

5. Structured milestone reporting on progress helps identify and address challenges.

6. Resource mobilisation and grant writing skills are key and must be incorporated in capacity development plans early enough in the programme.

\section{Additional files}

Additional file 1: List of peer-reviewed manuscripts published during the SHARE programme. (XLSX $70 \mathrm{~kb}$ )

Additional file 2: List of researchers networks created during the SHARE programme. (XLSX $12 \mathrm{~kb})$

\section{Abbreviations}

LMICs: low- and middle-income countries; LSHTM: London School of Hygiene and Tropical Medicine; SHARE: Sanitation and Hygiene Research in Africa and Asia: the SHARE Research Consortium; WASH: Water, Sanitation and Hygiene

\section{Acknowledgements}

We would like to thank all the participants of the different studies that SHARE consortium worked on. We also would like to dedicate this paper to Jeroen Ensink, for his enthusiasm and dedication to the capacity-building of the SHARE programme and his passion towards WASH research and training.

\section{Authors' contributions}

BT and RC drafted the first version of the paper. All the authors from the consortium reviewed and contributed to this manuscript. All authors read and approved the final manuscript.

\section{Funding}

The SHARE consortium programme was funded by the Department of International Development (DFID).

\section{Availability of data and materials \\ Not applicable.}

\section{Ethics approval and consent to participate}

Not applicable.

\section{Consent for publication}

Not applicable.

\section{Competing interests}

The authors declare that they have no competing interests.

\section{Author details}

'Department of Disease Control, London School of Hygiene and Tropical Medicine, Keppel Street, London WC1E 7HT, United Kingdom. ${ }^{2}$ Center for Infectious Disease Research in Zambia, Lusaka, Zambia. ${ }^{3}$ Centre for Water, Sanitation, Hygiene and Appropriate Technology Development, University of Malawi - The Polytechnic, Blantyre, Malawi. ${ }^{4}$ Mwanza Intervention Trials Unit, Mwanza, Tanzania. ${ }^{5}$ Great Lakes University of Kisumu, Kisumu, Kenya. ${ }^{6}$ WaterAid, London, United Kingdom. ${ }^{7}$ WaterAid Tanzania, Dar es Salaam, Tanzania.
Received: 8 January 2019 Accepted: 15 July 2019

Published online: 05 August 2019

\section{References}

1. Prüss-Üstün A, et al. Safer Water, Better Health: Costs, Benefits and Sustainability of Interventions to Protect and Promote Health. Geneva: WHO. 2008

2. Bartram J, Cairncross S. Hygiene, sanitation, and water: forgotten foundations of health. PLoS Med. 2010;7(11):e1000367.

3. World Health Organization. Progress on drinking water, sanitation and hygiene: 2017 update and SDG baselines. Geneva: WHO; 2017.

4. United Nations. Sustainable Development Goal 6: Ensure Access to Water and Sanitation for All. Washington, DC: UN; 2015.

5. Nchinda TC. Research capacity strengthening in the south. Soc Sci Med. 2002:54(11):1699-711.

6. Chunga RM, et al. Adopt or adapt: sanitation technology choices in urbanizing Malawi. PLoS One. 2016;11(8):e0161262.

7. Chunga $\mathrm{R}$, et al. Moving up the sanitation ladder with the help of microfinance in urban Malawi. J Water Sanit Hyg Dev. 2018;8(1):100-12.

8. Routray $P$, et al. Women's role in sanitation decision making in rural coastal Odisha, India. PLoS One. 2017;12(5):e0178042.

9. Routray $\mathrm{P}$, et al. Socio-cultural and behavioural factors constraining latrine adoption in rural coastal Odisha: an exploratory qualitative study. BMC Public Health. 2015:15(1):880.

10. Routray $P$, et al. Processes and challenges of community mobilisation for latrine promotion under Nirmal Bharat Abhiyan in rural Odisha, India. BMC Public Health. 2017:17(1):453.

11. Simiyu S. Socio-economic dynamics in slums and implications for sanitation sustainability in Kisumu, Kenya. Dev Pract. 2015;25(7):986-96.

12. Simiyu S. Determinants of usage of communal sanitation facilities in informal settlements of Kisumu, Kenya. Environ Urban. 2016;28(1): 241-58.

13. Simiyu $\mathrm{S}$, et al. Determinants of quality of shared sanitation facilities in informal settlements: case study of Kisumu, Kenya. BMC Public Health. 2017:17(1):68

14. Simiyu $\mathrm{S}$, et al. Estimating the cost and payment for sanitation in the informal settlements of Kisumu, Kenya: a cross sectional study. Int J Environ Res Public Health. 2017;14(1):49

15. Simiyu S. Preference for and characteristics of an appropriate sanitation technology for the slums of Kisumu, Kenya. Int J Urban Sustainable Dev. 2017;9(3):300-12.

16. Simiyu S, Cairncross S, Swilling M. Understanding living conditions and deprivation in informal settlements of Kisumu, Kenya. In Urban Forum. Netherlands: Springer; 2019:30(2):223-41.

17. Huda TMN, et al. A cross sectional study of the association between sanitation type and fecal contamination of the household environment in rural Bangladesh. Am J Trop Med Hyg. 2018;98(4):967-76.

18. Antwi-Agyei $P$, et al. A farm to fork risk assessment for the use of wastewater in agriculture in Accra, Ghana. PLoS One. 2015;10(11):e0142346.

19. Agyei PA, Awuah E, Oduro-Kwarteng S. Faecal sludge management in Madina, Ghana. J Appl Tech Env Sanit. 2011;1(3):239-49.

20. Antwi-Agyei P, Maalekuu B. Determination of microbial contamination in meat and fish products sold in the Kumasi metropolis (a case study of Kumasi central market and the Bantama market). Merit Res J Agric Sci Soil Sci. 2014:2(3):38-46.

21. Antwi-Agyei $P$, et al. Risk perceptions of wastewater use for urban agriculture in Accra, Ghana. PLoS One. 2016;11(3):e0150603.

22. Antwi-Agyei $P$, et al. A faecal exposure assessment of farm workers in Accra, Ghana: a cross sectional study. BMC Public Health. 2016:16(1):587.

23. Gautam OP, et al. Trial of a novel intervention to improve multiple food hygiene behaviors in Nepal. Am J Trop Med Hyg. 2017:96(6): 1415-26.

24. Balls E. Applying outcome mapping to plan, monitor and evaluate policy influence; learning from the SHARE research consortium: SHARE Learning Paper Report. 2018

25. Trostle J, Simon J. Building applied health research capacity in lessdeveloped countries: problems encountered by the ADDR project. Soc Sci Med. 1992:35(11):1379-87.

26. Greenwood B, Bhasin A, Targett G. The Gates Malaria Partnership: a consortium approach to malaria research and capacity development. Tropical Med Int Health. 2012;17(5):558-63. 
27. Hunter PR, et al. Needs assessment to strengthen capacity in water and sanitation research in Africa: experiences of the African SNOWS consortium. Health Res Policy Syst. 2014;12:68.

28. Binka F. North-South research collaborations: a move towards a true partnership? Tropical Med Int Health. 2005;10(3):207-9.

29. Chu KM, et al. Building research capacity in Africa: equity and global health collaborations. PLoS Med. 2014;11(3):e1001612.

30. Pang T, Lansang MA, Haines A. Brain drain and health professionals: a global problem needs global solutions. BMJ. 2002;324(7336):499.

31. Wolffers I, Adjei $S$, van der Drift R. Health research in the tropics. Lancet. 1998;351(9116):1652-4.

\section{Publisher's Note}

Springer Nature remains neutral with regard to jurisdictional claims in published maps and institutional affiliations.

Ready to submit your research? Choose BMC and benefit from:

- fast, convenient online submission

- thorough peer review by experienced researchers in your field

- rapid publication on acceptance

- support for research data, including large and complex data types

- gold Open Access which fosters wider collaboration and increased citations

- maximum visibility for your research: over $100 \mathrm{M}$ website views per year

At BMC, research is always in progress.

Learn more biomedcentral.com/submissions 